\title{
SAINTIFIK:
}

\section{Pengembangan Bahan Ajar Matematika Rekayasa Berbasis Pendidikan Islam}

\author{
Milawaty Waris*1, Muh. Tamrin ${ }^{2}$ \\ ${ }^{1}$ Universitas Sulawesi Barat, ${ }^{2}$ Sekolah Tinggi Agama Islam Al-Ghazali Bone; \\ e-mail: *1mayla_132@yahoo.com,$\underline{{ }^{2} \text { fahmitamrin170@gmail.com }}$
}

\begin{abstract}
Abstrak
Penelitian ini merupakan penelitian pengembangan dengan tujuan untuk mengembangkan dan melaksanakan proses penilaian terhadap kualitas bahan ajar mata kuliah matematika rekayasa berbasis Islam pada Program Studi Teknik Sipil Universitas Sulawesi Barat. Tujuan penelitian ini untuk memfasilitasi pencapaian penalaran mahasiswa. Jenis penelitian ini menggunakan jenis penelitian dengan metode Research \& Development (R\&D) yang mengacu pada model 4-D (Four D Models) yaitu Define, Design, Develop and Disseminate. Sampel dalam penelitian ini adalah mahasiswa program studi teknik sipil angkatan 2017 sebanyak 30 mahasiswa. Berdasarkan hasil uji coba terbatas yang dilakukan, diperoleh hasil validasi bahan ajar termasuk kategori valid.. Berdasarkan hasil pengamatan, keterlaksanaan bahan ajar yang dikembangkan menunjukkan bahwa rata-rata semua komponen pengamatan keterlaksanaannya termasuk kategori terlaksana seluruhnya (praktis). Empat kriteria yang menjadi acuan yaitu hasil belajar mahasiswa tercapai, efektif, ideal, dan memenuhi kriteria batas toleransi pencapaian waktu ideal yang digunakan. hasil rata-rata kemampuan dosen dalam mengelola pembelajaran berada pada kriteria tinggi dan hasil respon dari mahasiswa dikategorikan positif. Disimpulkan bahwa pada tahap uji coba terbatas dilaksanakan, bahan ajar matematika rekayasa berbasis Islam telah memenuhi kriteria kevalidan, kepraktisan, dan keefektifan.
\end{abstract}

Kata kunci Bahan Ajar, Pendidikan islam, Respon mahasiswa

\section{PENDAHULUAN}

Secara etimologis, matematika dapat diartikan sebagai ilmu pengetahuan yang diperoleh dengan berpikir. Matematika tumbuh dan berkembang karena proses berpikir sehingga logika adalah dasar untuk terbentuknya matematika.Matematika mengajarkan pentingnya waktu bahkan matematika merupakan kunci menguak misteri tentang sifat-sifat Allah SWT (Callie, 2014). Allah SWT mendesain dan mencipta alam semesta penuh dengan keteraturan dan ketepatan. Alam semesta disusun dengan hukum-hukum yang dapat dipahami melalui prinsip-prinsip matematis. Dengan demikian, matematika menyediakan wawasan untuk mengenal sifat-sifat Allah melalui keteraturan dan ketepatan hukum-hukum alam semesta. Alasan lainnya mengapa perlu belajar matematika, karena semua bidang kehidupan memerlukan matematika. Matematika tidak hanya diperlukan untuk pengembangan sains, teknologi, dan matematika sendiri. Bidang-bidang kehidupan lainnya seperti ekonomi, sosial, psikologi, kesehatan, politik, seni, musik, dan komunikasi juga memerlukan matematika. Oleh karena itu, matematika disebut bahasa universal (Abdusysyakir. 2006).

Belajar pada hakikatnya merupakan suatu proses perubahan kepribadian berupa kecakapan, sikap, kebiasaan, dan kepandaian sebagai suatu hasil dari latihan atau pengalaman. Sedangkan pembelajaran adalah suatu proses interaksi antara mahasiswa dengan dosen dan sumber belajar pada suatu lingkungan belajar. Pada tahapan proses pembelajaran,dosen diharapkan mampu membentuk tingkah laku yang diinginkan dengan menyediakan lingkungan atau stimulus dan menciptakan suasana yang kondusif sehingga pembelajaran dapat berjalan lancar dan efisien dengan mengacu pada standar proses pembelajaran yang merupakan kriteria penilaian tentang pelaksanaan pembelajaran pada program studi untuk memperoleh capaian pembelajaran lulusan.(Permenristekdikti No.44;2015 pasal 10). Pembelajaran matematika dapat

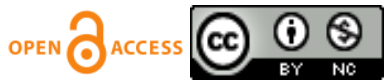


membentuk logika berpikir bukan hanya sekedar pandai berhitung. Matematika pada dasarnya mengajarkan logika berpikir, berdasarkan akal dan nalar. Namun, harus diingat sifat matematika itu abstrak dan tidak nyata karena terdiri dari simbol-simbol. Dengan demikian, matematika sebagai ilmu pengetahuan bisa digunakan sebagai pendekatan dalam menjelaskan beberapa penjelasan dalam ajaran Islam. Pendidikan yang berbasis pada nilai-nilai islam akan membentuk kepribadian yang baik. Nilai-nilai islam dapat diintegrasikan dalam proses pembelajaran matematika sehingga dapat mengantarkan mahasiswa untuk mencapai pengetahuan (kognitif), pemahaman dan penerapan nilai-nilai islam. Oleh sebab itu diperlukan suatu rumusan pembelajaran matematika yang mengintegrasikan nilai islam pada topik-topik matematika sekolah (Kohar, 2012).

Bahan ajar merupakan seperangkat materi yang disusun secara sistematis berupa materi yang akan dikuasai mahasiswa dalam proses pembelajaran. Bahan ajar harus didesain sedemikian rupa agar dapat memfasilitasi kebutuhan peserta didik dan mempermudah dalam proses pembelajaran. Sehingga perlu dilakukan sebuah pengembangan bahan ajar yang memenuhi kriteria untuk mencapai tujuan pembelajaran dapat memberikan makna pada mahasiswa dalam belajar. Mata Kuliah Matematika rekayasa dalam ilmu teknik sipil merupakan pengetahuan dasaryang diperlukan didalam menempuh jenjang pendidikan yang lebih tinggi. Matematika rekayasa dalam teknik sipil merupakan ilmu berhitung sebagai sarana berpikir ilmiah yang sangat diperlukan untuk menambah kemampuan berpikir logis, sistematis dan kritis dalam diri peserta didik. Mata kuliah matematika rekayasa merupakan sarana penunjang dalam mempelajari mata pelajaran lain terutama yang di dalamnya berkenaan dengan unsur-unsur perhitungan yang bersifat aplikatif. Bahan ajar untuk mata kuliah matematika rekayasa ini dirancang dengan memasukkan nilai-nilai pendidikan yang berbasis Islam, karena materi yang ada sangat berhubungan erat. Materi Bahan ajar untuk mata kuliah matematika rekayasa di program studi teknik sipil Universitas Sulawesi Barat harus lebih diberdayakan dan diubah menyentuh semua aspek, yaitu yang berbasis nilai-nilai pendidikan Islam/spiritual, sosial, pengetahuan, dan ketrampilan sehingga dapat berkontribusi lebih besar dalam pembentukan watak dan kepribadian mahasiswa.Sementara Pendidikan Islam mengajarkan nilai-nilai yang dapat membentukan kepribadian berkarakter, berakhlak mulia dan beradab. (Nurhidayanti,2017).

Pentingnya matematika bagi manusia dalam menjalankan tugasnya sebagai hamba Allah ('abdullah) dan sebagai wakil Allah di muka bumi (khalifatullah fil ardl). Matematika tidak dapat dipisahkan dari kehidupan manusia. Karena menjalankan tugas sebagai 'abdullah dan khalifatullah adalah suatu kewajiban maka belajar matematika juga menjadi kewajiban, walaupun Imam Al-Ghazali menggolongkannya sebagai fardlu kifayah (Abdussyakir,2006). Jadi, matematika bukan bagian yang terpisah dari agama. Praktik keagamaan membutuhkan matematika dan penggunaan matematika perlu dibimbing dengan agama.

\section{METODE PENELITIAN}

Jenis penelitian ini adalah penelitian dan pengembangan (Research and Development, $R \& D$ ). dengan mengadaptasi model pengembangan 4-D, yaitu Define, Design, Develop, and Dissminate (Sugiyono, 2013). Produk yang akan dikembangkan dalam penelitian pengembangan ini adalah sebuah bahan ajar matematika rekayasa berbasis nilai-nilai pendidikan Islam. Subjek penelitian adalah mahasiswa angkatan 2017 semester genap tahun ajaran 2018/2019.

Instrumen pengumpulan data yang digunakan dalam penelitian ini sebagai berikut: (1) untuk mengukur kevalidan yaitu dengan menggunakan lembar validasi ahli, (2) untuk mengukur kepraktisan yaitu dengan menggunakan lembar observasi keterlaksanaan modul, dan (3) untuk mengukur keefektifan yaitu dengan menggunakan lembar observasi kemampuan dosen mengelola pembelajaran, angket respons mahasiswa, lembar observasi aktivitas mahasiswa dan tes hasil belajar (THB). Data yang telah dikumpulkan dengan menggunakan instrumen-instrumen seperti yang telah di sebutkan, selanjutnya di analisis secara kumutatif dan di arahkan untuk menjelaskan kevalidan, keefektifan dan kepraktisan modul berbasis masalah untuk memfasilitasi kemampuan penalaran mahasiswa. Adapun data hasil uji coba di kelas digunakan untuk menjelaskan keefektifan dan kepraktisan modul berbasis Islam untuk memfasilitasi kemampuan penalaran mahasiswa di program studi teknik Sipil Universitas Sulawesi Barat.

Pengumpulan data dalam penelitian ini menggunakan metode observasi, pengisian angket, dan dokumentasi. Instrumen pengumpulan data menggunakan lembar penilaian bahan ajar, lembar observasi, dan 
angket. Teknik analisis data meliputi pengembangan bahan ajar, kualitas bahan ajar dan respon mahasiswa. Pengembangan bahan ajar menggunakan pendekatan kualitatif yang terdiri dari pengumpulan data, reduksi data, penyajian data, penarikan kesimpulan dan verifikasi (Sugiyono, 2013). Keabsahan data dilakukan dengan triangulasi data. Triangulasi data merupakan teknik yang dilakukan peneliti dalam mengumpulkan data dengan menggunakan sumber data yang berbeda. Validasi dan penilaian dilakukan oleh dua dosen yang bekerja sama. Dosen yang satu berasal dari teknik sipil dan dosen yang satunya berasal dari pendidikan agama. untuk mengetahui kualitas bahan ajar dan mendapatkan saran guna perbaikan. Penilaian dari validator berupa data kualitatif diubah menjadi data kuantitatif kemudian dicari jumlah total, rata-rata, dan persentase keidealan. Uji coba produk terdiri dari uji coba terbatas dan uji coba luas untuk mengetahui kelayakan produk dan respon mahasiswa terhadap bahan ajar dan pembelajaran berbasis pendidikan nilai islam. Respon mahasiswa diperoleh dari pengisian angket kemudian dicari rata-rata persentase ideal.

\section{HASIL DAN PEMBAHASAN}

\subsection{Penyajian Data}

Data yang diperoleh dari penelitian ini adalah data Uji coba produk terdiri dari uji coba terbatas dan uji coba luas untuk mengetahui kelayakan produk dan respon mahasiswa terhadap bahan ajar dan pembelajaran berbasis nilai-nilai pendidikan Islam. Pengembangan bahan ajar matematika berbasis Islam dilakukan dengan menggunakan model 4-D. Tahap Pendefinisian (Define). Pertama analisis awal-akhir, analisis ini bertujuan untuk mengidentifikasi masalah-masalah yang dihadapi oleh dosen khususnya dosen yang mengajar mata kuliah matematika rekayasa di angkatan 2017. Berdasarkan hasil diskusi dengan team teaching tentang kegiatan pembelajaran matematika rekayasa dikampus tersebut, diperoleh bahwa proses pembelajaran mata kuliah matematika rekayasa di angkatan 2017 masih berpusat pada dosen. Kedua analisis mahasiswa, pada analisis ini, peneliti menelaah tentang latar belakang pengetahuan mahasiswa, bahasa yang digunakan dan tingkat perkembangan kognitif mahasiswa. Ketiga Analisis Konsep, Kegiatan yang dilakukan pada tahap ini adalah mengidentifikasi, merinci, dan menyusun secara sistematis materi-materi utama yang dipelajari mahasiswa, selanjutnya materi tersebut disusun secara sistematis. Keempat analisis tugas, pada tahap ini, peneliti merumuskan tugas berdasarkan indikator yang ada dalam pembelajaran matematika rekayasa. Kelima spesifikasi tujuan pembelajaran, dilakukan dengan menjabarkan kompetensi dasar ke dalam indikator pencapaian hasil belajar yang lebih spesifik berdasarkan analisis materi dan analisis tugas.

Tahap Perancangan (Design), peneliti mulai merancang bahan ajar matematika berbasis masalah untuk memfasilitasi pencapaian kemampuan penalaran. Hasil perancangan tersebut terdiri dari (1) judul, pada tahap merancang judul dilihat berdasarkan kompetensi dasar, indikator yang ingin dicapai, materi pokok, dan didasarkan oleh suatu strategi, maka bahan ajar ini diberi judul "Bahan Ajar Matematika rekayasa Berbasis Islam", (2) kata pengantar, bagian ini berisi ucapan terima kasih atas terselesaikannya bahan ajar, alasan penulisan bahan ajar secara singkat dan manfaat yang bisa diperoleh dengan membaca bahan ajar tersebut, (3) informasi isi bahan ajar, bagian ini akan memberikan informasi penting tentang isi modul, (4) petunjuk penggunaan bahan ajar, bagian ini ditunjukkan apa saja yang mesti dilakukan peserta didik ketika membaca bahan ajar, (5) daftar isi, bagian ini menginformasikan kepada pembaca tentang topik-topik yang ditampilkan dalam bahan ajar sesuai urutan tampilan dan nomor halaman dengan demikian pembaca mudah untuk melacak materi yang dicari, tanpa harus membuka halaman demi halaman satu per satu, (6) kompetensi dasar, perilaku akhir yang diharapkan dapat diperoleh oleh pembaca dari hasil proses belajar yang ditempuhnya, itulah isi bagian ini, (7) indikator keberhasilan, bagian ini akan memberikan informasi penting tentang keberhasilan yang harus dicapai dalam modul, (8) indikator penalaran, bagian ini akan memberikan informasi penting tentang keberhasilan yang harus dicapai dalam modul, (9) peta konsep, bagian ini akan memberikan informasi penting tentang hubungan antar topik, sehingga peserta didik)lebih mudah melihat ruang lingkup materi secara komprehensif, (10) materi pokok, bagian ini berisi sejumlah materi pokok yang akan dibahas agar peserta didik menguasai kompetensi dasar yang ditetapkan, (11) uraian materi, jika materi pokok telah ditentukan, maka pada bagian ini lah materi pokok itu dijabarkan dan dijelaskan kebagianbagian yang lebih rinci dan mendetail. Selain itu, pada bagian ini terdapat aktivitas mahasiswa yang di dasarkan pada sintaks pembelajaran berbasis Islam. Dengan demikian peserta didik bisa memahaminya 
dengan mendalam, (12) tes mandiri, tes ini di berikan pada akhir setiap bab atau akhir setiap kegiatan belajar. Hal ini ditujukan untuk mengukur tingkat penguasaan materi yang dicapai oleh peserta didik pada setiap kegiatan belajarnya, (13) rangkuman, bagian ini memuat rangkuman materi dalam satu bab, sehingga terletak diakhir materi setiap bab, (14) refleksi, bagian tindak lanjut berisi feedback kepada pembaca. Bagi yang telah menguasai materi, disarankan untuk mengembangkan pengetahuan yang telah diperolehnya. Sedangkan bagi yang belum mencapai belajar tuntas, disarankan untuk mengulangi bagian yang masih dirasa sulit, (15) uji kompetensi, tes ini diberikan di akhir bahan ajar untuk melihat penguasaan peserta didik terhadap materi yang sudah dipelajari dalam satu bahan ajar. Waktu yang dibutuhkan untuk menyelesaikan tes akhir ini diusahakan tidak melebihi waktu yang digunakan untuk mempelajari bahan ajar, (16) daftar pustaka, sejumlah referensi yang digunakan sebagai bahan rujukan ditulis dalam bagian ini. Sehingga, jika peserta didik ingin mengetahui secara lengkap atau lebih jauh tentang suatu persoalan dari sumber referensi tertentu, maka dapat dilacak keberadaannya.

Tahap pengembangan (develop), pada tahap ini peneliti Pertama melakukan uji validitas terhadap bahan ajar yang dibuat berupa modul pembelajaran untuk memenuhi kriteria pertama pada bahan ajar yaitu bernilai valid.

Tabel 1. Hasil Uji Validitas Bahan Ajar Modul

\begin{tabular}{|c|c|c|c|}
\hline No & Lembar Validasi & Rata-rata Penilaian & Kategori \\
\hline 1 & Modul & 4,45 & Valid \\
\hline
\end{tabular}

Hasil menunjukkan bahwa penilaian untuk lembar validasi modul beserta perangkatnya memiliki nilai ratarata sebesar 4,45 dan dikategorikan valid karena berada pada interval $4 \leq M \leq 5$ selain itu semua validator memberikan kesimpulan bahwa perangkat yang telah dikembangkan adalah baik dan dapat digunakan dengan sedikit revisi. Kedua kemudian setelah divalidasi, bahan ajar tersebut di uji coba untuk memenuhi kriteria kepraktisan dengan menggunakan lembar observasi keterlaksanaan bahan ajar.

Tabel 2. Hasil Uji Kepraktisan Bahan Ajar

\begin{tabular}{|c|c|c|c|}
\hline No. & Lembar Penilaian & Rata-rata Penilaian & Kategori \\
\hline 1. & Keterlaksanaan Bahan ajar & 1,90 & Terlaksana Seluruhnya \\
\hline
\end{tabular}

Hasil uji kepraktisan bahan ajar menunjukkan bahwa rata-rata hasil penilaian keterlaksanaan bahan ajar matematika rekayasa berbasis Islam untuk memfasilitasi pencapaian kemampuan penalaran sebesar 1,90 dan dikategorikan hampir terlaksana seluruhnya (praktis) dengan interval penilaian berada pada interval $1,5 \leq X$ $\leq 2$.

Tabel 3. Hasil Uji Keefektifan Perangkat Bahan Ajar

\begin{tabular}{|c|l|l|c|}
\hline No. & \multicolumn{1}{|c|}{ Lembar Penilaian } & \multicolumn{1}{|c|}{ Penilaian } & Kategori \\
\hline 1. & Tes Hasil Belajar (THB) & $\begin{array}{l}\text { Hasil belajar siswa tercapai } \\
\text { karena 85\% siswa mencapai } \\
\text { skor 75 }\end{array}$ & Efektif \\
\hline 2. & Aktivitas Mahasiswa & $\begin{array}{l}\text { Telah memenuhi kriteria } \\
\text { batas toleransi pencapaian } \\
\text { waktu ideal yang digunakan }\end{array}$ & Efektif \\
\hline 3. & $\begin{array}{l}\text { Kemampuan Dosen dalam } \\
\text { Mengelola Proses }\end{array}$ & $\begin{array}{l}\text { Hasil rata-rata yang diperoleh } \\
\text { yaitu 3,80 dan berada pada } \\
\text { kriteria tinggi dalam interval } \\
3,5 \leq K G<4,5 .\end{array}$ & Efektif \\
\hline 4. & $\begin{array}{l}\text { Angket Respon yang di isi } \\
\text { oleh Mahasiswa }\end{array}$ & $\begin{array}{l}\text { Hasil respon positif terhadap } \\
\text { bahan ajar modul yang } \\
\text { dikembangkan berbasis Islam } \\
\text { lebih dari 50\% yaitu 85,79\%. }\end{array}$ & Efektif \\
\hline
\end{tabular}


Dari keempat kriteria keefektifan dapat disimpulkan bahwa pada tahap uji coba terbatas telah dilaksanakan dan perangkat pembelajaran yang berupa bahan ajar matematika rekayasa berbasis masalah tersebut yang bertujuan untuk memfasilitasi pencapaian kemampuan penalaran mahasiswa telah memenuhi kriteria kevalidan, kepraktisan, dan keefektifan. Tahap penyebaran (disseminate) tidak dilakukan karena keterbatasan waktu dan biaya, dengan harapan akan dilanjutkan oleh peneliti selanjutnya.

\subsection{Kualitas Bahan Ajar Matematika Berbasis Islam yang Dikembangkan}

Kevalidan berdasarkan hasil uji kevalidan yang telah dibahas sebelumnya dapat disimpulkan bahwa prototype awal bahan ajar matematika rekayasa berbasis masalah untuk memfasilitasi pencapaian kemampuan penalaran siswa beserta perangkat pendukungnya yang telah dikembangkan telah memenuhi kriteria kevalidan. Meskipun sebelumnya telah dilakukan beberapa revisi kecil sesuai saran yang diberikan oleh dua validator. Kepraktisan, secara teoritis, hasil penilaian ahli dan praktisi dalam bidang pendidikan matematika terhadap bahan ajar matematika rekayasa berbasis Islam untuk memfasilitasi pencapaian kemampuan penalaran mahasiswa menyatakan bahwa bahan ajar layak digunakan dalam pembelajaran, sedangkan berdasarkan hasil pengamatan terhadap perangkat bahan ajar oleh dua observer menyatakan bahwa perangkat modul terlaksana dengan baik pada saat uji coba. Berdasarkan hasil penilaian pengamat, maka perangkat bahan ajar telah memenuhi kriteria kepraktisan. Keefektifan, kriteria keefektifan bahan ajar, dapat dinilai melalui: (1) hasil belajar mahasiswa atau ketuntasan klasikal, (2) respon mahasiswa, (3) aktivitas mahasiswa, (4) kemampuan dosen dalam mengelola pembelajaran. Kriteria yang harus dipenuhi sehingga suatu perangkat bahan ajar dikatakan efektif adalah memenuhi 3 kriteria tetapi indikator ketuntasan hasil belajar harus dipenuhi. Dari hasil uji coba yang dilakukan pada mahasiswa program studi teknik sipil universitas sulawesi barat, keempat kriteria yang menuju keefektifan termasuk dalam kategori terpenuhi.

\section{KESIMPULAN}

Hasil yang diperoleh dari proses pengembangan bahan ajar mata kuliah matematika rekayasa di program studi teknik sipil universitas sulawesi barat dengan menggunakan model 4-D yang terdiri dari 4 tahap yaitu pendefinisian (define), perancangan (design), dan pengembangan (develop), dan tahap penyebaran (desseminate). Berdasarkan hasil pengembangan bahan ajar diperoleh bahan ajar yang valid, praktis, dan efektif.

\section{DAFTAR PUSTAKA}

Abdusysyakir. 2006. Ada Matematika dalam Al-Qur'an. Malang: UIN Malang Press

Callie. (2014). Nilai-nilai Keislaman. Jakarta: Ufuk Press.

Kohar, Ahmad Wachidul. (2012).Integrasi Nilai Islam dalam Pembelajaran Matematika. (Online), http://Bangqohar.wordpress.comIntegrasi-Nilai-Islam-dalam-Pembelajaran-Matematika, diakses tanggal 1 November 2014.

Nurhidayati, S. (2017) "Pengembangan bahan ajar matematika berbasis Masalah untuk memfasilitasi pencapaian kemampuan penalaran pada pokok bahasan perbandingan kelas VII MTSn Model".Mapan: Jurnal Matematika dan Pembelajaran Volume 5, No 2, Desember 2017 UIN Alauddin Makassar (236250)

Permenristekdikti (2015). Standar peraturan menteri riset dan teknologi pasal 10

Sugiyono. (2013). Metode penelitian kualitatif kuantitatif dan R\&D. Bandung: Alfabeta. 